\title{
Deformations of Land, Sea and Gravity Levels by the 2009 Samoa Earthquake
}

\author{
Nils-Axel Mörner ${ }^{1}$, Albert Parker², Pamela Matlack-Klein ${ }^{3}$ \\ ${ }^{1}$ Paleogeophysics \& Geodynamics, Stockholm, Sweden \\ ${ }^{2}$ Independent Scientist, Bandoora, Australia \\ ${ }^{3}$ The Portuguese Sea Level Project, Porto, Portugal \\ Email: *morner@pog.nu
}

How to cite this paper: Mörner, N.-A., Parker, A. and Matlack-Klein, P. (2018) Deformations of Land, Sea and Gravity Levels by the 2009 Samoa Earthquake. International Journal of Geosciences, 9, 579-592.

https://doi.org/10.4236/ijg.2018.910034

Received: September 5, 2018

Accepted: September 27, 2018

Published: September 30, 2018

Copyright (C) 2018 by authors and Scientific Research Publishing Inc. This work is licensed under the Creative Commons Attribution International License (CC BY 4.0).

http://creativecommons.org/licenses/by/4.0/

\begin{abstract}
The Samoa Islands were struck by the September 2009 earthquake of $M_{w}$ 8.1. We study the effect on the land level by means of GPS monitoring and on ocean level by tide-gauge records. This allows us to present a new picture of the interaction of crustal movements, gravitational adjustment and sea level changes. The land level exhibits a co-seismic uplift followed by a post-seismic crustal subsidence. The ocean level records a fall, significantly larger than the uplift and delayed by several months, followed by a significant rise, by far exceeding the crustal subsidence and delayed by several months. This indicates a significant contribution from changes in gravity (geoidal eustasy), besides relative sea level changes due to crustal movements. High amplitude, and high frequency changes in tidal range provide evidence of changes in gravity and geoidal eustasy.
\end{abstract}

\section{Keywords}

The Samoa Islands, 2009 Earthquake and Tsunami, GPS Records,

Tide-Gauge Stationas at Apia and Pago Pago, Short-Term

Gravity Changes

\section{Introduction}

The Samoa Islands are located in the Southwest Pacific just to the NE of the active plate boundary marked by the Kermadec-Tonga subduction zone (Figure 1). The area has been struck by a number of high-magnitude earthquakes. We investigate the effects of the September 29,2009 , earthquake $\left(M_{w} 8.1\right)$ on the land level (by GPS) and the sea level (by tide-gauges) in the Samoa Islands; the stations on Upolu Island in Samoa and on Tutuila Island in American Samoa. 


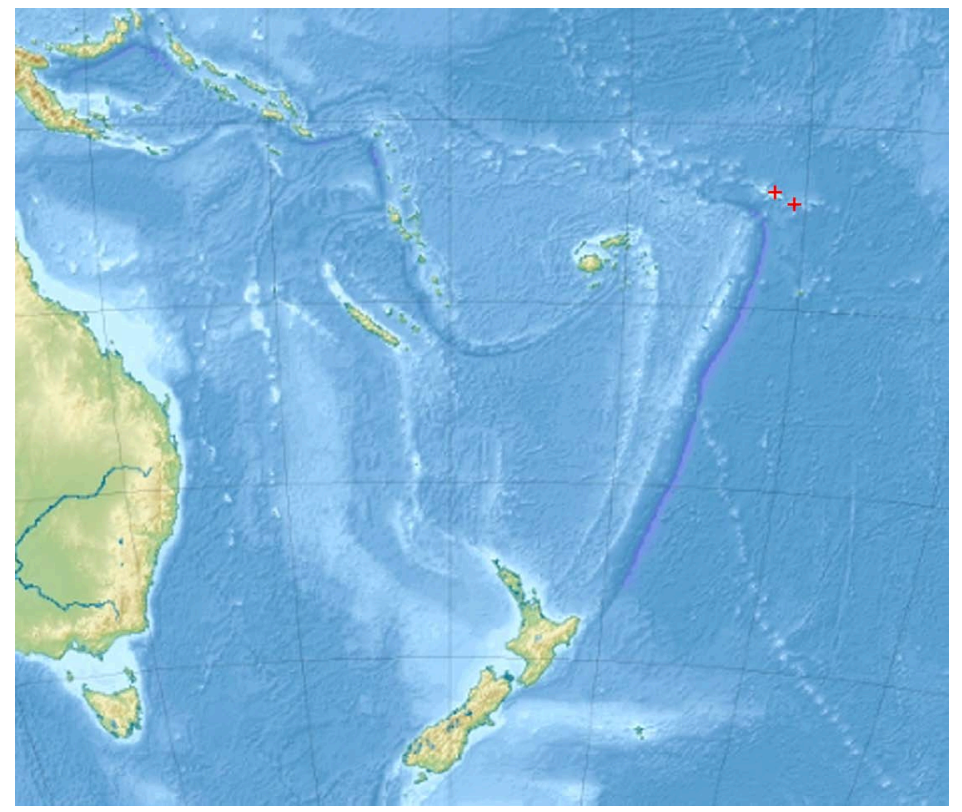

Figure 1. Location of the Samoa Islands (red crosses) to the NE of the Kermadec-Tomga subduction zone.

\section{Geological Setting}

The Kermadec-Tonga subduction zone (Figure 1) is a part of the notorious " $\mathrm{Pa}$ cific Ring of Fire" named for its high seismic and volcanic activity in association with plate collision and subduction at a rate of about $24 \mathrm{~cm} / \mathrm{yr}$ [1] [2] [3] [4]. Therefore, it is no surprise that the Tonga-Samoa region has experienced numerous high magnitude earthquakes in recent times [5] [6].

Figure 2 summarizes earthquake events up to 2010 affecting the Samoa Islands. A major additional earthquake of $\mathrm{M}_{\mathrm{w}} 8.5$ occurred in June 26, 2017. The present paper will be focused on the September 29, 2009, earthquake of $M_{w} 8.1$ and its effects as recorded on the Samoa Islands.

The Samoa and American Samoa Islands constitute a chain of islands continuing to the west in a number of submerged seamounts [3] [7]. The age of the islands grows younger to the east with an active submarine volcano located 30 $\mathrm{km}$ the east of Ta'u Island (Figure 3). This is consistent with a plate moving westwards over a fixed hot spot. The Samoan hot spot seems to have existed for at least 23 million years [3]. Volcanic rocks of the Savai'i Island, the Upolu Island and the Tutuila Island have been dated at 5.21 Ma, 3.2 - 1.4 Ma and 1.53 1.0 Ma, respectively (Figure 3).

Volcanic rock from the Machias Seamount south of Upolu Island (Figure 3) has been dated at $0.97 \mathrm{Ma}$. Because the top of the seamount, today at a depth of about $700 \mathrm{~m}$, seems to have been deposited under subaerial conditions [7] [8], it must have subsided by about $700 \mathrm{~m}$ or at a mean long-term rate in the order of $0.7 \mathrm{~mm} / \mathrm{yr}$.

The hot spot chain of active submarine volcano, Samoan islands and submerged seamounts are likely to be dominated by a long-term subsidence. Differential 


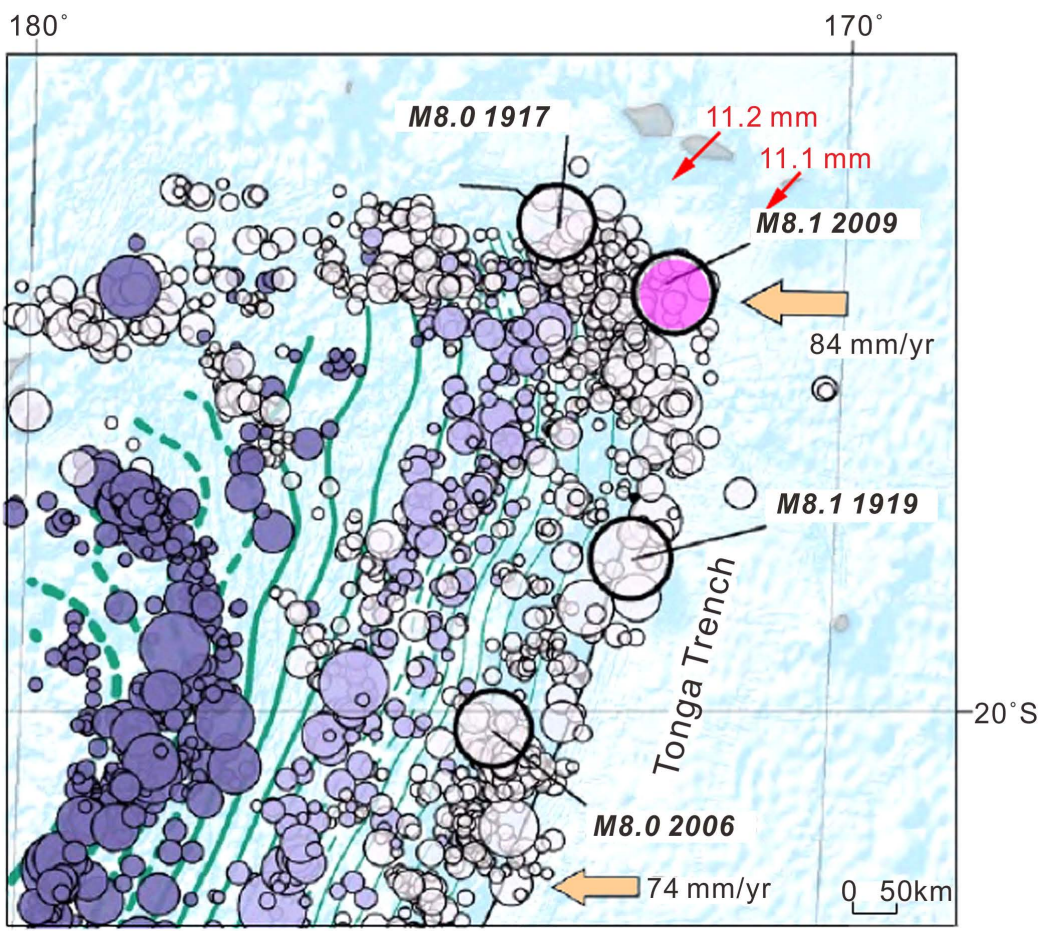

Figure 2. Seismicity of the northern part of the Kermadec-Tonga subduction zone to the southwest of the Samoa Islands: earthquake up to 2010, subduction line and increasing slab depth to the west (maximum $700 \mathrm{~km}$ deep). The position of the September 29, 2009, earthquake is marked in purple. Red arrows on Upolu Island and Tutuila Island in the Samoa Islands give the co-seismic slip rate recorded; i.e., a horizontal slip of about $11 \mathrm{~mm}$ towards the SW.

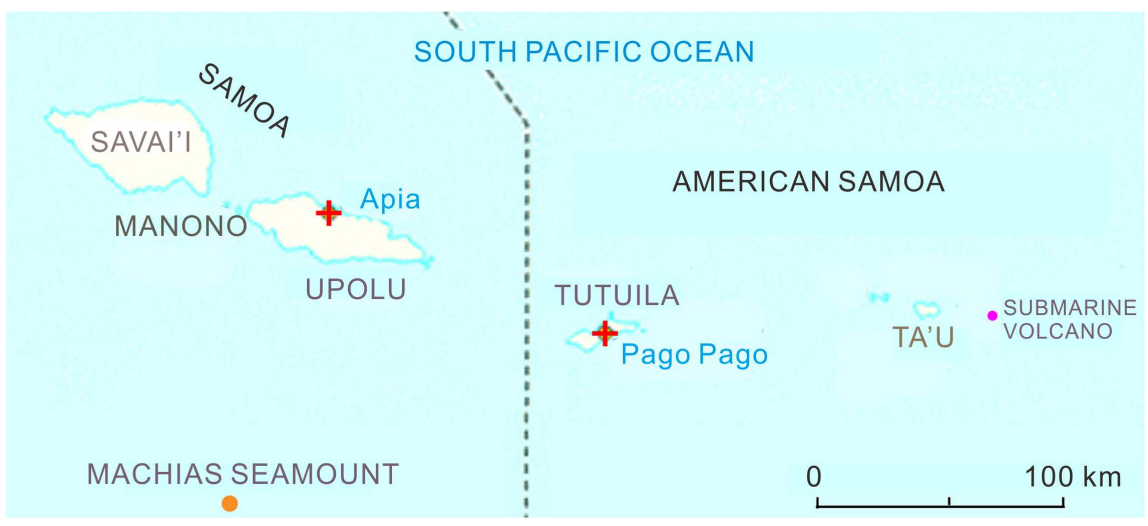

Figure 3. The Samoa Islands with the location of the tide-gauge and GPS stations at Apia, and the American Samoa with the location of the tide-gauge and GPS stations at Pago Pago. The islands constitute a hot-spot chain of volcanic eruption centra with the present center at the submarine volcano in the east.

crustal movements and seismo-tectonic deformations are likely also to have occurred.

Calculating Holocene subsidence rates from former sea level data calls for some sort of stable reference level. Some authors have used an assumed Mid Holocene high sea level datum, which implies that their calculations remain 
quite hypothetical [9] [10].

Dickinson [9] mentions two sites on Upolu Island; a beachrock at about $\pm 0 \mathrm{~m}$ at Maninoa (westernmost Upolu) dated at about $4400 \mathrm{BP}$, and a beachrock at $-2.25 \mathrm{~m}$ at Mulifanua (south central Upolu) dated at about $2800 \mathrm{BP}$. In comparison with our studies in Fiji [11], this would, in the first case, imply stability and, in the second case, a subsidence of about $0.6 \mathrm{~mm} / \mathrm{yr}$.

Sand et al. [10] investigated the Manono Island just west of Upolu (Figure 2). They record a habitation layer at a level between present mean and low tide level dated at about $2100 \mathrm{BP}$. With a corresponding sea level at about $-0.5 \mathrm{~m}$ [11] this would suggest a minor subsidence in the order of $0.25-0.50 \mathrm{~mm} / \mathrm{yr}$ (certainly much less than the rate of $-1.1-1.2 \mathrm{~mm} / \mathrm{yr}$ as suggested by Sand et al., 2016).

Goodwin and Grossman [12] undertook a stratigraphic and sedimentological survey at two sites on the south-central part of Upolu Island. The data cover the last 4500 years and record the interaction of modest changes in sea level and crustal movements. It seems not possible to isolate any long-term trends, however.

\section{The $\mathbf{M}_{\mathrm{w}}$ 8.1 Earthquake and Tsunami in 2009}

On September 29, 2009, the Samoa region was struck by a magnitude $M_{w} 8.1$ earthquake [5] [13]. The epicenter was located $200 \mathrm{~km}$ south of the main Samoan Island chain, and at a depth of about $18 \mathrm{~km}$ below the seafloor. The earthquake was caused by normal faulting in association with the bend of the plate boundary SW of the Samoan Islands (Figure 4).

Because it was a normal faulting in the seabed, it set up a huge tsunami composed of, at least, 4 separate waves [14] [15]. The maximum tsunami wave height

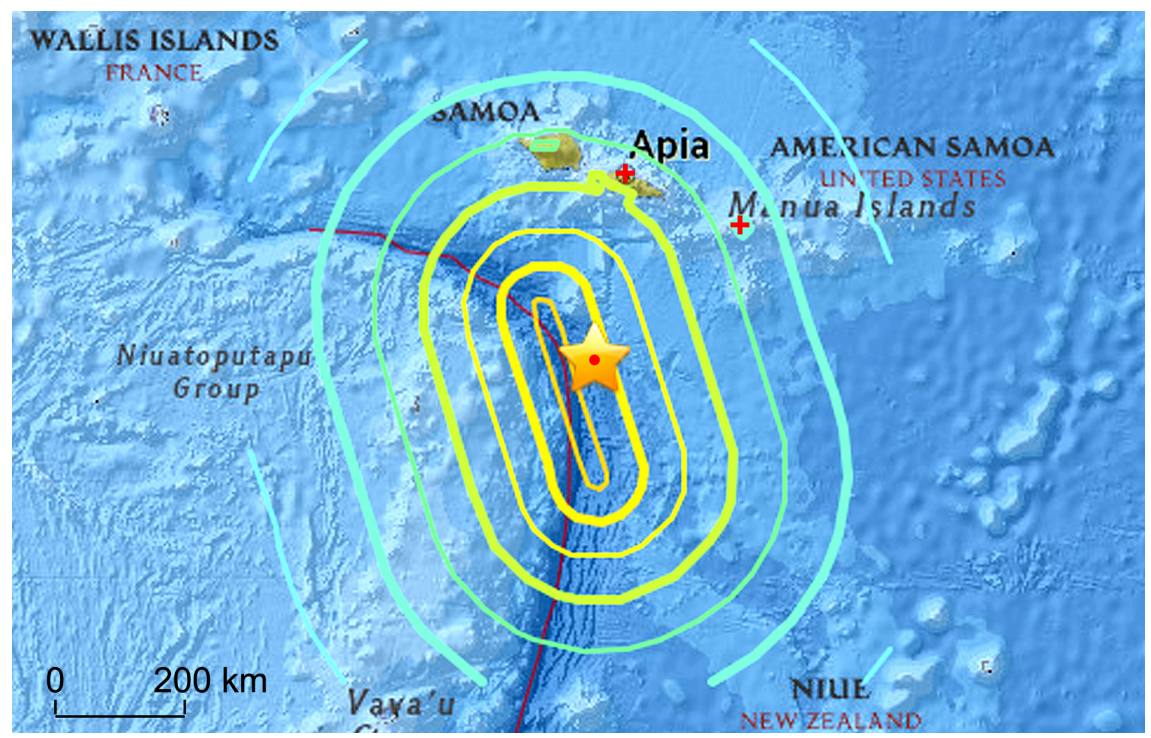

Figure 4. The Samoa 2009 earthquake originated from a normal fault just east of the main subduction boundary (Hayes et al., 2017). At Apia (Samoa Islands) and Pago Pago (American Samoa) is recorded in a co-seismic vertical jump and a horizontal SW jump of $11 \mathrm{~mm}$. 
was $11.9 \mathrm{~m}$, which implies that it reached a maximum level in the relation between earthquake magnitude and tsunami wave height [16].

The tsunami had disastrous effects along the coasts of the Samoa and Tonga Islands [5]. In total, 183 people were killed in the Samoa Islands.

Because it was a normal fault seismic event, we can a priori assume that the seafloor was affected by vertical crustal movements. The a posteriori proof of subsidence comes both from GPS records and from tide-gauge records to be explored below.

\section{The GPS Records at Samoa and American Samoa}

Continual measurements of changes in the land level by means of GPS are available from Upolu Island in Samoa and from Tutuila Island in American Samoa (Figure 3). The records are accessible from the SONEL [17] and JPL [18] databases. The SONEL records are more detailed but end in 2014. The JPL records end in 2018, and hence provide a longer record.

\subsection{Tutuila Island in American Samoa}

The GPS station (known as the ASPA station) lies $7 \mathrm{~km}$ to the NE of the tide gauge station location. The SONEL [19] record provides a very detailed record of the changes in land level from 2002 to 2014 (Figure 4). It gives a perfect image of the crustal response to a major earthquake; viz a pre-earthquake period of stability, an instantaneous co-seismic jump of $+3.58 \mathrm{~cm}$ at the September 29 earthquake of 2009, followed by a post-seismic subsidence of $9.10 \mathrm{~cm}$ in the first 4 years. The post-seismic subsidence decreases exponentially. It represents a crustal relaxation from the earthquake deformation. The rate of subsidence for the last 2 years (2012-2014) was $10.5 \mathrm{~mm} / \mathrm{yr}$ (Figure 5). The pre-seismic rate is hard to see in Figure 5 graph of daily data. A graph of the weekly data from 2002

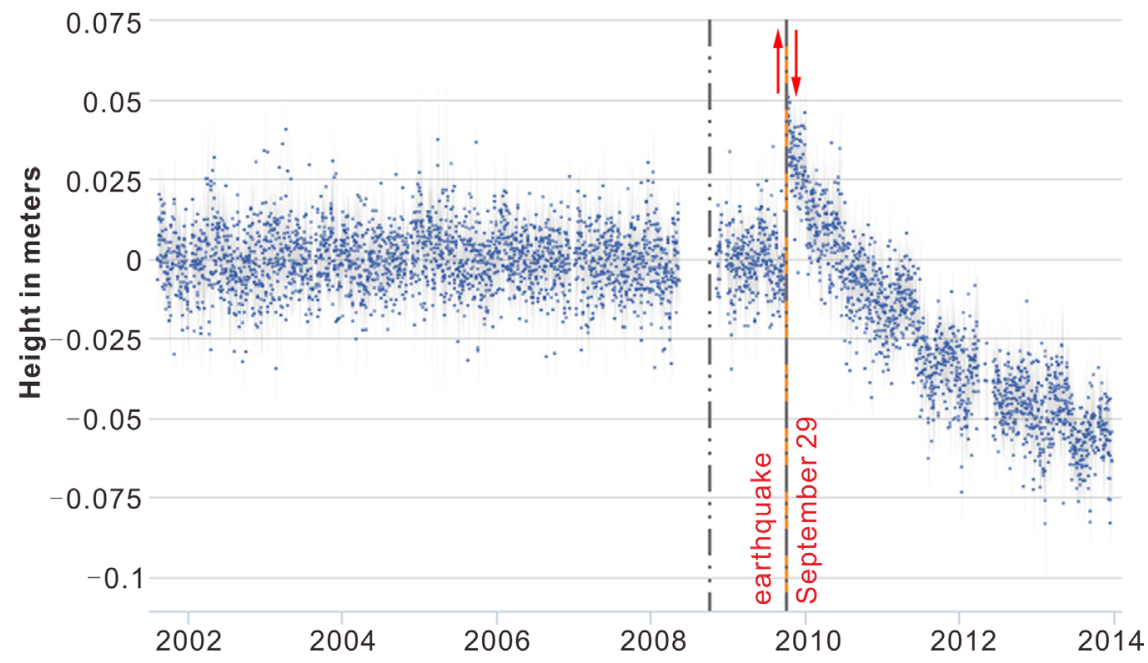

Figure 5. GPS record of the September 29, 2009, deformation at the ASPA station on Tutuila Island; a co-seismic jump of $+3.58 \mathrm{~cm}$ followed by a post-earthquake subsidence [19]. 
to 2008 [19] gives a continual mean subsidence of $-0.60 \pm 0.20 \mathrm{~mm} / \mathrm{yr}$. This is important, because it suggests that Tutuila Island may be experiencing a weak long-term subsidence.

The JPL record [20] covers the period 2002-2018 (Figure 6). It shows a pre-seismic period of weak subsidence $(0.07 \mathrm{~mm} / \mathrm{yr})$. There is no record of the co-seismic vertical uplift so well documented in Figure 5. There is a clear post-seismic subsidence; a rapid fall of $-3.87 \mathrm{~cm}$ followed by a subsidence, which for the last 6 years had a mean rate of $10.0 \mathrm{~mm} / \mathrm{yr}$. Consequently, the subsidence has continued for more than 8 years.

The horizontal components (latitude and longitude) record a co-seismic slip of $11.1 \mathrm{~mm}$ to the SW in $134^{\circ}$ (Figure 2; [20]).

Figure 6 record shows a total absence of traces of the June 26, 2017, $\mathrm{M}_{\mathrm{w}} 8.5$ earthquake, indicating that this earthquake followed other mechanisms and spatial distributions.

\subsection{Upolu Island in Samoa}

The GPS station (at Fagali'i airport) is located $3.5 \mathrm{~km}$ to the SE of Apia, where the tide gauge station is located. The SONEL [21] record provides a good record of the changes in land level from 2002 to 2014 (Figure 7), although the record is not as clear as the one from Tutuila Island (Figure 4). It shows a fragmentary pre-seismic record, a co-seismic jump in the order of $2-3 \mathrm{~cm}$, and a post-seismic subsidence in the order of $6-7 \mathrm{~cm}$.

The JPL [22] covers the period 2002-2018 (Figure 8). It shows a pre-seismic period of weak subsidence $(-1.17 \mathrm{~mm} / \mathrm{yr})$, and a post-seismic subsidence beginning with a $-1.44 \mathrm{~cm}$ subsidence in the first year followed by a continual subsidence of $-5.89 \mathrm{~mm} / \mathrm{yr}$ during the last 8 years.

The pre-seismic rate of subsidence $(-1.17 \mathrm{~mm} / \mathrm{yr})$ is important because is suggests that the Upolu Island may be experiencing a weak long-term subsidence.

The horizontal components (latitude and longitude) record a co-seismic slip of $11.2 \mathrm{~mm}$ to the $\mathrm{SW}$ in $130^{\circ}$ (Figure 2; [22]).

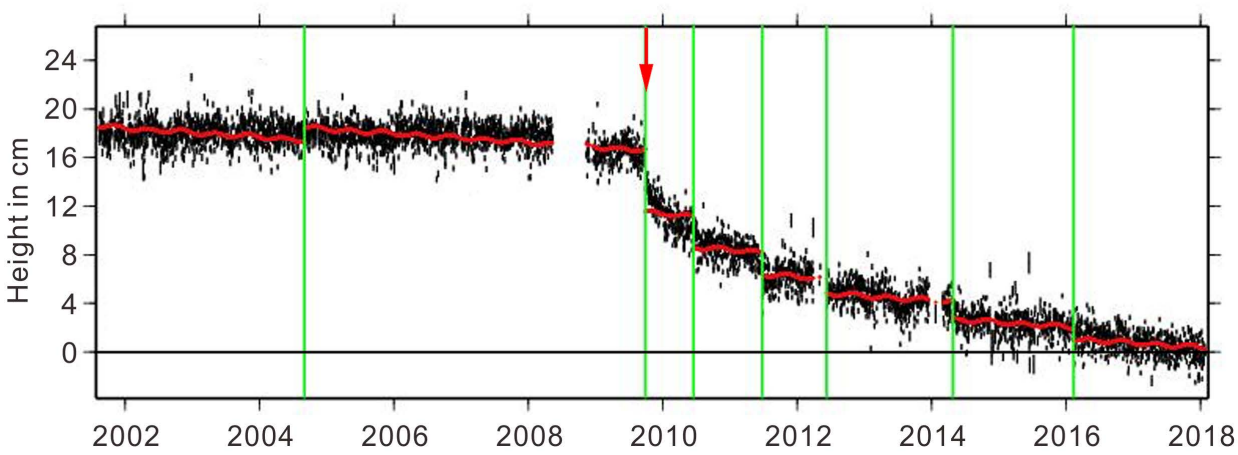

Figure 6. GPS according to JPL [20] showing a weak pre-seismic subsidence of $0.07 \mathrm{~mm} / \mathrm{yr}$ and an exponential decreasing post-seismic subsidence; a rapid fall of $-3.87 \mathrm{~cm}$ followed by a mean rate over the last 6 years of $-10.0 \mathrm{~mm} / \mathrm{yr}$. 


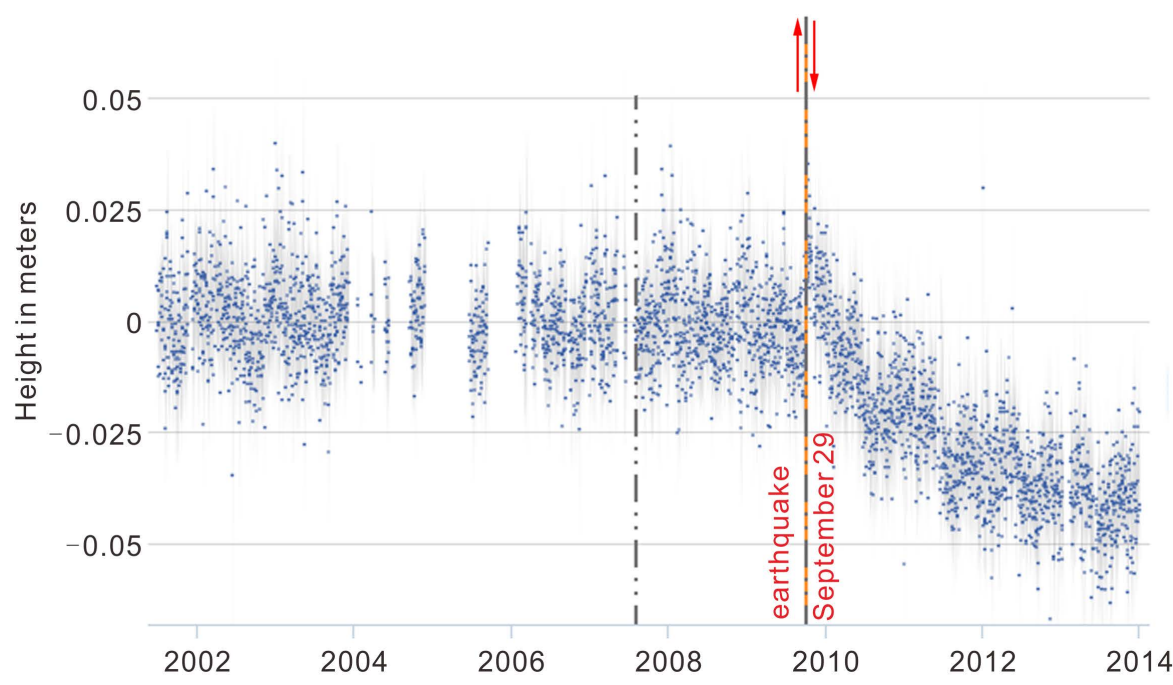

Figure 7. GPS record of the September 29, 2009, deformation at the station SE of Apia on Upolu Island; a co-seismic jump in the order of $2-3 \mathrm{~cm}$ followed by a post-earthquake subsidence of $6-7 \mathrm{~cm} \mathrm{[21].}$

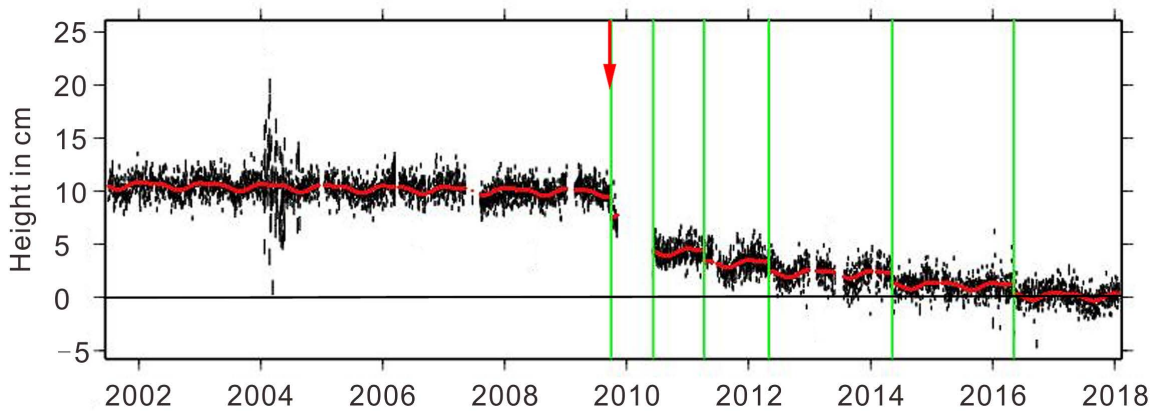

Figure 8. GPS according to JPL [22] showing a weak pre-seismic subsidence of -1.17 $\mathrm{mm} / \mathrm{yr}$, no co-seismic uplift but a post-seismic subsidence beginning with a rapid fall of $-1.44 \mathrm{~cm}$ followed by a fairly stable subsidence of $-5.89 \mathrm{~mm} / \mathrm{yr}$ during the last years 7 years.

Figure 8 record shows a total absence of traces of the June 26, 2017, $M_{w} 8.5$ earthquake, indicating that this earthquake followed other mechanisms and spatial distributions.

\section{Tide Gauge Records at Apia and Pago Pago}

There are two tide gauges; one at Pago Pago on Tutuila Island in American Samoa (station 539; [23]) and one at Apia on Upolu Island in Samoa (station 1840; [24]) and. The location of the stations is marked in Figure 3.

\subsection{The Tide-Gauge at Pago Pago}

The tide-gauge of Pago Pago, American Samoa, is managed by NOAA/NOS [25]. The source of data is PSMSL [23], station 539. It covers the period 1948-2016 with a completeness of $93 \%$ (Figure 9). Spanning 68 years, this record qualifies for analysis of sea level changes. 
At a superficial view, Figure 9 may look like recording a sea level acceleration $\left(\right.$ of $\left.+0.152 \mathrm{~mm} / \mathrm{yr}^{2}\right)$. A more correct analysis reveals that it records a pre-seismic relative sea level rise (partly due to subsidence) of $-2.21 \pm 0.81 \mathrm{~mm} / \mathrm{y}$ [25], a somewhat unclear co-seismic sea level fall (due to uplift) of $5-8 \mathrm{~cm}$, and post-seismic sea level rise of $19-22 \mathrm{~cm}$ within a year (due to subsidence and gravitational effects) followed by variations around a seemingly stable level during the last 6 years.

\subsection{Tide-Gauge at Apia}

The Apia tide-gauge station is, in fact, two separate stations. Station 743 of PSMSL [26] covers the period 1954-1971 (with a completeness of 82\%). It shows a fairly straight trend of $-0.19 \mathrm{~mm} / \mathrm{yr}$. Much more important is the Apia-B station or station 1840 of PSMSL [24]. It covers the period 1993-2016 with a completeness of 97\% (Figure 10). Since 1998, it is a part of the Australian National Tidal Facility SEAFRAME project [27].

The Apia-B station records a pre-seismic sea level rise of $1.99 \mathrm{~mm} / \mathrm{yr}$, a co-seismic sea level fall (uplift) of $4.55 \mathrm{~cm}$ lasting for 4 months, and a post-seismic rapid rise in sea level of $10.0 \mathrm{~cm}$ lasting for 12 months and followed by semi-stability during the last 6 years.

By comparison with the GPS records (Figure 6 and Figure 7), we can be sure that the signal in 2010 is caused by the 2009 earthquake, and has nothing to do with the ENSO-events recorded in 1998, 2005 and 2016.

The SEAFRAME [27] data provides an improved picture of the deformation in sea level in association with the 2009 earthquake (Figure 11). Figure 11 gives separate graphs for the high-tide level (HTL), the mean-tide level (MTL) and the low-tide level (LTL) with a tidal range in the order of $1.35 \mathrm{~m}$. No changes of any of the tidal parameters are recorded right at the earthquake on September 29, 2009. In December 2009, the low-tide level starts to fall, and by mid-January,

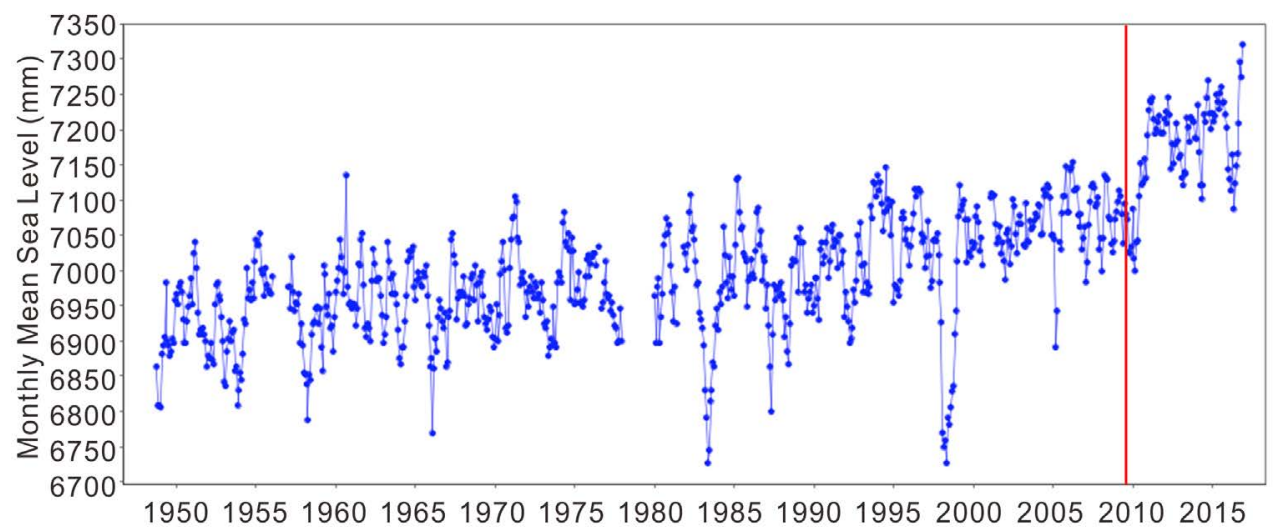

Figure 9. Tide-record from Pago Pago with the date of the 2009 earthquake marked with red line. At the earthquake, there was a $5-8 \mathrm{~cm}$ fall in sea level (due to the co-seismic uplift) followed by a $19-22 \mathrm{~cm}$ rapid rise in sea level in 2010 (due to the post-seismic subsidence and changes in gravity) and fluctuations around a stable mean sea level in following 5 years (to be compared with the GPS record of Figure 5). The low peaks in 1983, 1998, 2005 and 2016 mark ENSO events. 


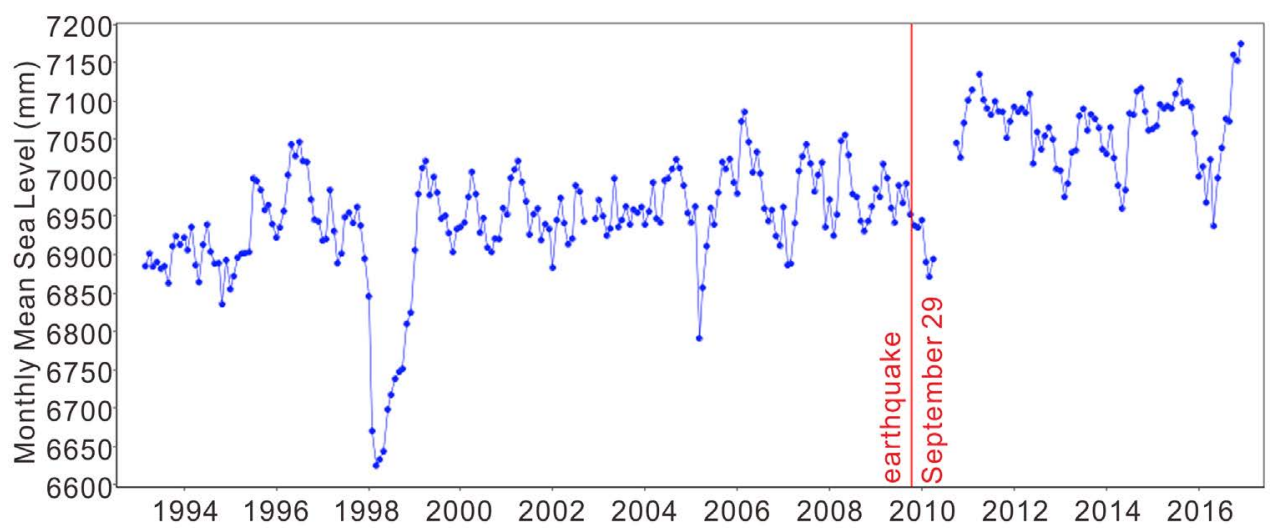

Figure 10. Tide-gauge record from the Apia station recording a pre-seismic sea level rise of -0.19 $\mathrm{mm} / \mathrm{yr}$, a co-seismic sea level fall (due to uplift) of $4.55 \mathrm{~cm}$ and a post-seismic rapid rise in sea level of $10.0 \mathrm{~cm}$ lasting for 12 months (due to subsidence and gravitational changes) followed by fluctuations around a stable mean sea level during the last 6 years (to be compared with the GPS record of Figure 7). The 1998 sea level drop refers to the ENSO event in 1998.

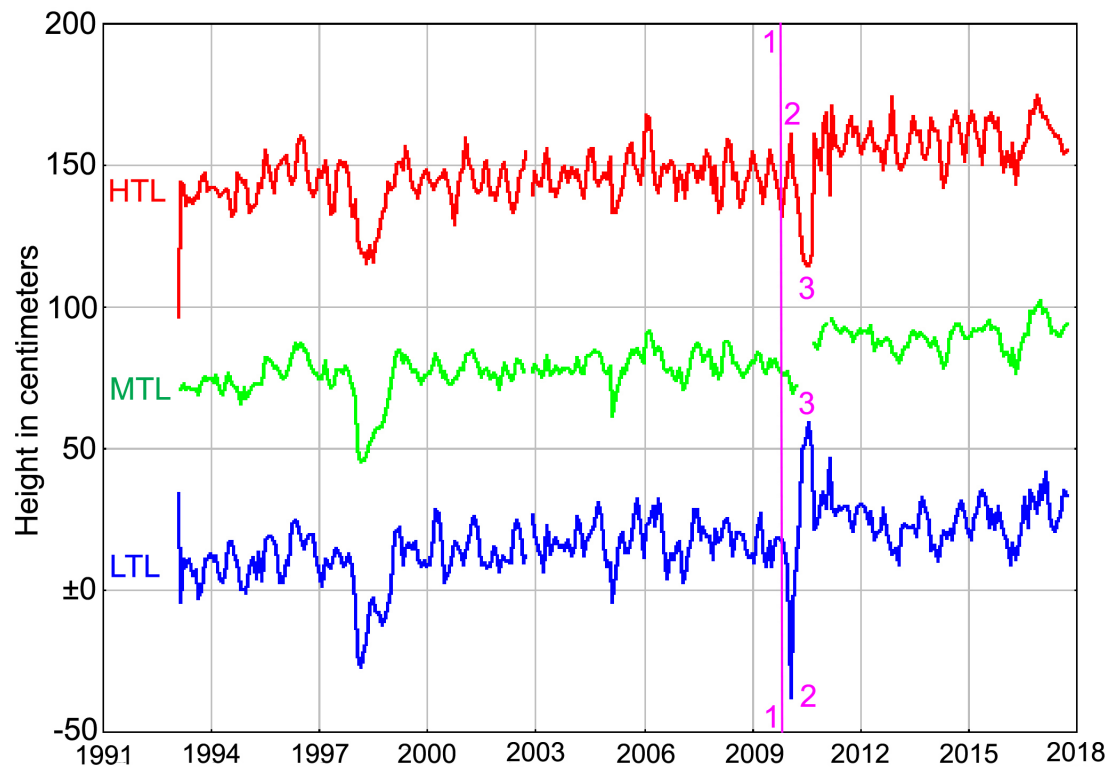

Figure 11. Complete tide-gauge record from Apia (SEAFRAME, 2018) with changes in high-tide level (HTL), mean-tide level (MTL) and low-tide level (LTL). Besides the crustal movements recorded in MTL (cf. Figure 10), there were significant changes in tidal range. (1) The earthquake strikes, (2) by mid-January 2010, the tidal range has increased by $65 \mathrm{~cm}$, and (3) by mid-June 2010, it has decreased by $80 \mathrm{~cm}$. The 1998 and 2005 signals are ENSO events.

2010 (i.e., 3.5 months after the earthquake), it has fallen by $42.0 \mathrm{~cm}$. At the same time, the tidal range has increased to $2.0 \mathrm{~m}$ (i.e., a rise by $65 \mathrm{~cm}$ ). Then the trend reverses and by mid-June, 2010 (i.e., 9.5 months after the earthquake), the low-tide level rises by $98 \mathrm{~cm}$ at the same time as the high-tide level falls by about $46 \mathrm{~cm}$, giving a tidal range of only $55 \mathrm{~cm}$.

Figure 12 gives the changes in tidal range from 1993 up to 2017. It shows minor oscillation within a zone of $125-145 \mathrm{~cm}$. Right after the 2009 earthquake, 


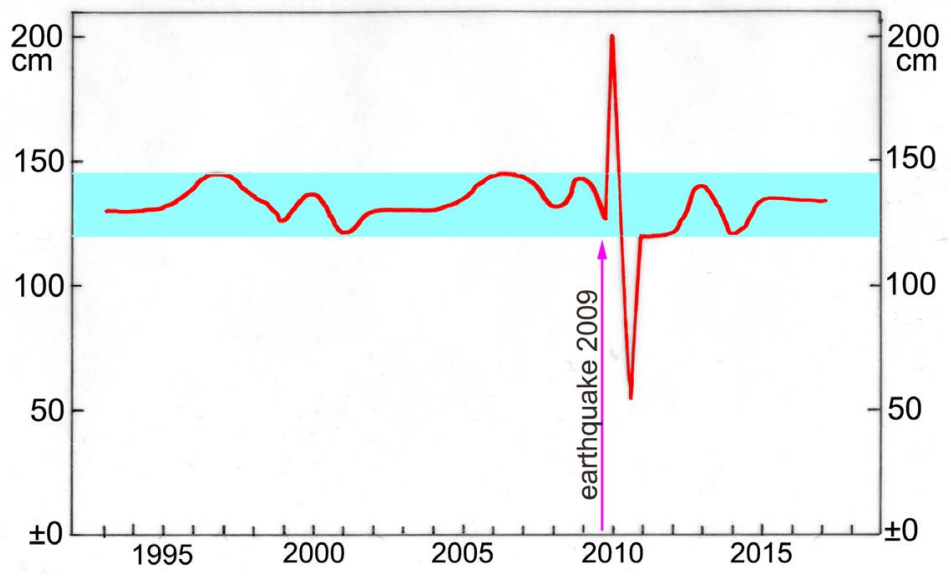

Figure 12. Changes in tidal range recorded at the Apia station (Figure 11). The normal level fluctuates between 125 and $145 \mathrm{~cm}$ (marked with a blue zone). Right after the 2009 earthquake, the tidal range increased to $200 \mathrm{~cm}$ and then fell to $55 \mathrm{~cm}$, indicating significant changes in gravity in association to the seismically induced crustal movements. This is a novel observation on coastal seismotectonics.

the tidal range experiences very strong swings; viz by $+65 \mathrm{~cm}$ in mid-January and $-80 \mathrm{~cm}$ in mid-June. This can only be understood in terms of significant changes in gravity involved in the post-earthquake changes. This is a novel and important observation, which makes any recalculation of observed relative sea level changes during the first years following the earthquake very complicated, if not impossible.

The changes in mean sea level (MTL) record a $7.1 \mathrm{~cm}$ lowering in mid-January, 2010, followed by a $25.0 \mathrm{~cm}$ rise up to mid-February, 2011 ( 16.7 months after the earthquake). This is similar to the uplift/subsidence signals recorded in the PSMSL mean sea level record of Figure 10, and the GPS uplift/subsidence record of Figure 7 . The amplitude changes $(-7.1 \mathrm{~cm}$ and $+25.0 \mathrm{~cm})$ are larger than in Figure 10.

Figure 12 and Figure 13 graphs reveal that we-as a function of the 2009 earthquake-are dealing with a complicated interaction in crustal movements, gravitational compensation and sea level changes. This means that sea level analyses should be restricted to the pre-seismic period.

\section{Discussion}

The earthquake magnitude $\left(M_{w} 8.1\right)$ and geographical extension reaching far beyond the Samoa Islands (Figure 3) imply that direct effects are likely to have affected both land and sea levels in the Samoan Islands.

The GPS stations on Upolu and Tutuila Islands (Figure 3) both record an instantaneous co-seismic uplift followed by an exponentially decaying subsidence (Figures 5-8).

The tide-gauge station close-by on the same islands both record a sea level fall followed by a sea level rise (Figure 9 and Figure 10). The tidal parameters from the Upolu station (Figure 11) show large changes in the tidal range; first an 


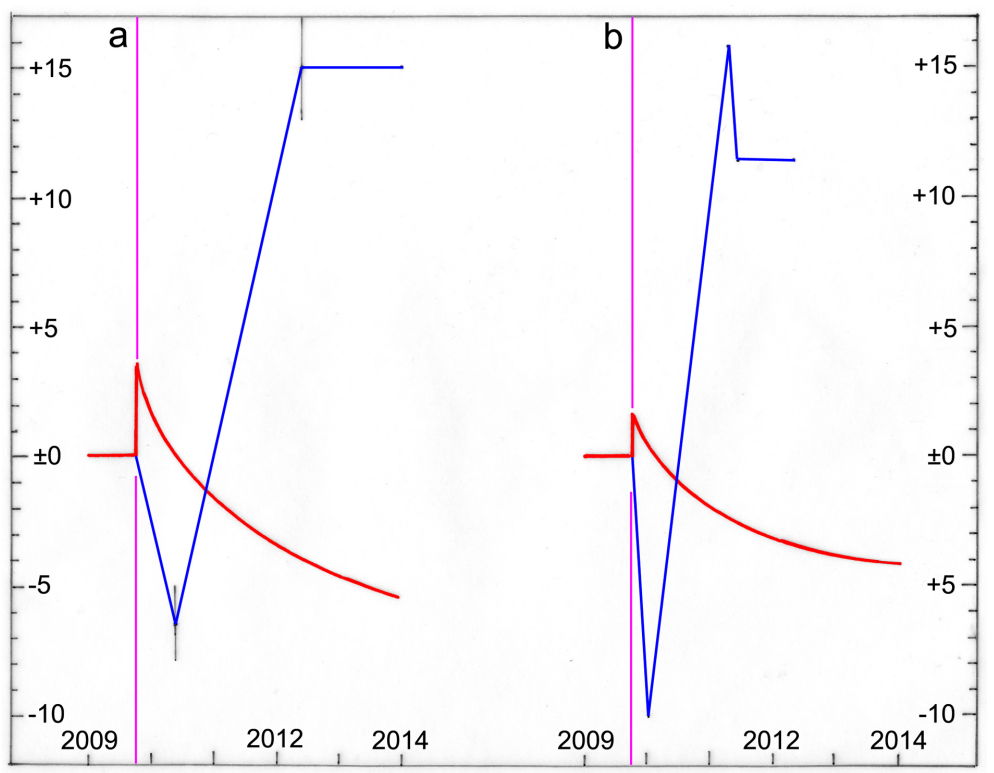

Figure 13. Synthesis of the observed change in land level (red) and sea level (blue) at the stations on Tutuila Island (a) and Upolu Island (b) in association with the September 29, 2009, $\mathrm{M}_{\mathrm{w}} 8.1$ earthquake (purple line).

increase of $65 \mathrm{~cm}$, then a decrease of $80 \mathrm{~cm}$ with respect to the normal tidal range of about $135 \mathrm{~cm}$. This indicates that changes in gravity are connected with the post-seismic changes in crustal and ocean levels.

In Figure 13, we plot the changes in land level (red) and ocean level (blue recorded at the stations on Tutuila (a) and Upolu (b) Islands.

Right at the earthquake, the land levels jumps up by a few $\mathrm{cm}$. This uplift is followed by a subsidence from a slowly relaxing crust, recorded by an exponentially decaying subsidence (continuing for, at least, a decade). This post-seismic subsidence is interpreted in terms of a viscoelastic response of the upper mantle [28] [29].

The ocean level shows a fall taking a few months to culminate. The falls in sea level by far exceed the amount of uplift. Together with the delay in culmination, this enhanced fall in sea level (with respect to amount of uplift) is indicative of simultaneous gravitational changes deforming the gravitational potential surface (or geoid). The same applies for the subsequent rise in sea level, which, by far, exceeds the post-seismic crustal subsidence. Besides, it is significantly delayed with respect to the crustal subsidence phase.

In conclusion, Figure 13 records a combination of crustal movements, gravitational change due to tectonics and geoidal eustatic changes in sea level [30].

The apparent sea level acceleration at Pago Pago (Figure 9) is revealed as illusive due to the co- and post-seismic changes in land and sea levels. The real mean rate of sea level changes seems to be in the order of $0.88 \mathrm{~mm} / \mathrm{yr}$ with an acceleration of only $+0.0252 \mathrm{~mm} / \mathrm{yr}^{2}$ [31].

Besides the co-seismic vertical changes in crustal level, there was also a co-seismic slip in horizontal direction [20] [22] of about $11 \mathrm{~mm}$ (as shown by 
arrows in Figure 2). This is indicative of sudden horizontal slip in the under-thrusting of the Pacific Plate of the Australia Plate.

\section{Conclusions}

We have demonstrated that an earthquake in September, 2009, affected the land level of Upolu Island in the Samoan Islands and Tutuila Island in American Samoa by initiating a co-seismic uplift followed by crustal subsidence, and the ocean level at the same islands by sea level fall followed by sea level rise. Even the tidal amplitude was significantly deformed due to short-term changes in gravity and geoidal eustasy [30].

The effects of the 2009 earthquake observed imply the interaction of crustal deformation, gravitational compensation and changes in sea level as summarized below.

Co-seismic effects:

- Vertical crustal “jump” of $3.58 \mathrm{~cm}$ (Tutuila) and 2 - $3 \mathrm{~cm}$ (Upolu);

- Sea level fall of 5 - $8 \mathrm{~cm}$ (Pago Pago, Tutuila) and $4.55 \mathrm{~cm}$ (Apia, Upolu);

- Horizontal "jump" in the rate of sea flow spreading by $11 \mathrm{~mm}$;

- Tsunami event of $11.9 \mathrm{~m}$ maximum wave height.

Post-seismic effects:

- Subsidence; exponentially decaying;

- Sea level rise of $21.5 \mathrm{~cm}$ at Pago Pago and $25.9 \mathrm{~cm}$ at Apia followed by more stable conditions during the last 6 years;

- Rapid changes in tidal range $( \pm 50 \mathrm{~cm}$ in 2011$)$ driven by high-amplitude, short-frequency changes in gravity and geoidal eustasy.

Only by combining different records of the changes in land and ocean levels was it possible to decode the complicated geodynamic processes linked to the 2009 earthquake.

The multiple forces interacting in the post-earthquake sea level changes make available tide-gage records from the Samoan Islands quite unsuitable for sea level studies of the post-2009 period.

\section{Acknowledgements}

AP called attention to available data, NAM wrote up the paper in collaboration with the others, and PMK corrected the paper linguistically. The paper was presented by NAM at the $9^{\text {th }}$ PATA conference in Paleoseismology, Active Tectonics and Archaeoseismology in Possidi, Greece, June 25, 2018 [32].

An anonymous reviewer asked for further information about the principles of GPS measurements. The network, principles and errors of vertical land motions are well covered by SONEL in http://www.sonel.org/-Vertical-land-movement-estimate-.html.

\section{Conflicts of Interest}

We declare no competing interest. 


\section{References}

[1] Bevis, M., Taylor, F.W., Schutz, B.E., Recy, J., Isacks, B.L., Helu, S., Singh, R., Kendrick, E., Stowell, J., Taylor, B. and Calmant, S. (1995) Geodetic Observations of Very Rapid Convergence and Back-arc Extension at the Tonga arc. Nature, 374, 249-251. https://doi.org/10.1038/374249a0

[2] Smith, I.E.M. and Price, R.C. (2006) The Tonga-Kermadec and Le Havre-Lau Back arc System: Their Role in the Development of Tectonic and Magmatic Models for the Western Pacific. Journal of Volcanology and Geothermal Research, 156, 315-331.

[3] Neal, V.E. and Trewick, S.A. (2008) The Age and Origin of the Pacific Islands: A Geological Overview. Philosophical Transactions of the Royal Society B, 363, 3293-3308. https://doi.org/10.1098/rstb.2008.0119

[4] Kermadec-Tonga Subduction Zone. https://en.wikipedia.org/wiki/Kermadec-Tonga_subduction_zone

[5] EERI (2010) Samoa Earthquake and Tsunami of September 29, 2009. EERI Special Earthquake Report. https://www.eeri.org/site/images/eeri_newsletter/2010_pdf/Samoa-Rpt.pdf

[6] (2017) Samoa Earthquake. https://en.wikipedia.org/wiki/1917_Samoa_earthquake

[7] Natland, J.H. (2003) The Samoan Chain: A Shallow Lithospheric Fracture System. http://www.whoi.edu/science/GG/geodynamics/2004/images/Natland_Samoa2.pdf

[8] Coulbourn, W.T., Hill, P.J. and Bergersen, D.D. (1989) Machias Seamount, Western Samoa: Sediment Remobilization, Tectonic Dismemberment and Subduction of a Guyot. Geo-Marine Letters, 9, 119-125. https://doi.org/10.1007/BF02431038

[9] Dickinson, W.R. (2007) Upolu (Samoa): Perspective on Island Subsidence from Volcano Loading. Journal of Island \& Coastal Archaeology, 2, 236-238. https://doi.org/10.1080/15564890701520850

[10] Sand, C., Bole, J., Baret, D., Ouetcho, A.J., Petchey, F., Hogg, A. and Asaua, T. (2016) Geological Subsidence and Sinking Islands: The Case of Manono (Samoa). Archaeology in Oceania, 51, 99-107. https://doi.org/10.1002/arco.5099

[11] Mörner, N.-A. and Matlack-Klein, P. (2017) New Records of Sea Level Changes in the Fiji Islands. Oceanography \& Fishery, Open Access Journal, 5, 20.

[12] Goodwin, I.D. and Grossman, E.E. (2003) Middle and Late Holocene Coastal Evolution along the South Coast of Upolu Island, Samoa. Marine Geology, 202, 1-16. https://doi.org/10.1016/S0025-3227(03)00284-6

[13] Hayes,G.P., Meyers, E.K., Dewey, J.W., Briggs, R.W., Earlle, P.S., Benz, H.M., Smoczyk, G.M., Flamme, H.E., Barnhard, W.D., Gold, R.D. and Furlong, K.P. (2017) Tectonic Summaries of Magnitude 7 and Greater Earthquakes from 2000 to 2015. USGS Open-File Report 2016-1192.

https://earthquake.usgs.gov/earthquakes/eventpage/usp000h1ys\#executive

[14] Okal, E.A., Fritz, H.M., Synolakis, C.E., Borrero, J.C., Weiss, R., Lynett, P.J., Titov, V.V., Foteinis, S., Jaffe, B.E., Liu, P.L.-F. and Chan, I. (2010) Field Survey of the Samoa Tsunami of 29 September 2009. Seismological Research Letters, 81, 577-591. https://doi.org/10.1785/gssrl.81.4.577

[15] Okal, E.A., Borrero, J.C. and Chagué-Goff, C. (2011) Trunamigenic Predecessors to the 2009 Samoa Earthquake. Earth-Science Reviews, 107, 128-140. https://doi.org/10.1016/j.earscirev.2010.12.007

[16] Mörner, N.-A. (2017) Converting Tsunami Wave Heights to Earthquake Magnitudes. Open Journal of Earthquake Research, 6, 89-97. 
https://doi.org/10.4236/ojer.2017.62005

[17] SONEL (2018) GPS Data from Station 631 ASPA (American Samoa) and 831 (Samoa). http://www.sonel.org

[18] JPL (2018). http://sideshow.jpl.nasa.gov/post/links

[19] SONEL (2018). http://www.sonel.org/spip.php?page=gps\&idStation=631

[20] JPL (2018) American Samoa GPS Data. https://sideshow.jpl.nasa.gov/post/links/ASPA.html

[21] SONEL (2018). http://www.sonel.org/spip.php?page=gps\&idStation=831

[22] JPL (2018) Samoa GPS Data. https://sideshow.jpl.nasa.gov/post/links/SAMO.html

[23] PSMSL (2018). http://www.psmsl.org/data/obtaining/stations/539.php

[24] PSMSL (2018). http://www.psmsl.org/data/obtaining/stations/1840.php

[25] NOAA/NOS (2018) NOA's National Ocean Service. https://tidesandcurrents.noaa.gov/sltrends/sltrends.html

[26] PSMSL (2018). http://www.psmsl.org/data/obtaining/stations/743.php

[27] SEAFRAME (2018). http://www.bom.gov.au/ntc/IDO70062/IDO70062SLI.shtml

[28] Panet, I., Mikhailov, V., Diament, M., Pollits, F., King, G., de Viron, O., Holschneider, M., Biacale, R. and Lemoine, J.M. (2007) Coseismic and Post-Seismic Signatures of the Sumatra 2004 December and 2005 March Earthquakes in GRACE Satellite Gravity. Geophysical Journal International, 171, 177-190. https://doi.org/10.1111/j.1365-246X.2007.03525.x

[29] Wang, L., Shum, C.K., Simons, F.J., Tapley, B. and Dai, C. (2012) Coseismic and Postseismic Deformation of the 2011 Tohoku-Oki Earthquake Constrained by GRACE Gravimetry. Geophysical Research Letters, 39, L07301. https://doi.org/10.1029/2012GL051104

[30] Mörner, N.-A. (1976) Eustasy and Geoid Changes. Journal of Geology, 84, 123-151. https://doi.org/10.1086/628184

[31] Parker, A., Mörner, N.-A. and Matlack-Klein, P. (2018) Sea Level Acceleration Caused by Earthquake Induced Subsidence in the Samoa Islands. Ocean and Coastal Management, 1611, 11-19. https://doi.org/10.1016/j.ocecoaman.2018.04.017

[32] Mörner, N.-A. (2018) Changes in Land Level, Gravity and Sea Level at the 2009 Earthquake in Samoa. 9th International INQUA Workshop on Paleoseismology, Active Tectonics and Archaeoseismology, Possidi, 25-27 June 2018, 174-176. 